\title{
Clinical Analysis of Anaphylaxis Patients in an Emergency Medical Center
}

\author{
Kazushige Nakanishi, Yohko Nagai, Tatsuo Akimoto, Hirohito Kato, \\ Noriko Hara, Katsunori Yoshiwara, and Motonobu Sugimoto
}

\begin{abstract}
Clinical analysis was conducted for 26 patients who were transferred and admitted for emergency treatment of anaphylaxis in a secondary healthcare setting in Toho University Omori Medical Center during the two years between September 2003 and August 2005. Possible triggering factors for anaphylaxis were foods in 12 patients, drugs in 11 patients, and other factors (bee sting and rat and hamster bites) in three patients. The foods included fish for seven patients; meat, soba or buckwheat noodles, and citrus fruits for one patient each; and other foods for two patients. Five of the patients tested had positive results for a specific radioallergosorbent test (RAST). Drugs were all oral agents including non-steroidal anti-inflammatory drugs (NSAID) in eight patients and antibiotics in three patients. The results from a drug lymphocyte stimulation test (DLST) were positive for only two of the patients. All patients experienced cutaneous and respiratory symptoms. Seven patients experienced symptoms of disturbance of consciousness, and nine patients experienced symptoms of shock, either drug-induced (five patients) or food-induced (four patients). No significant difference was observed between the two groups. Nineteen of the 26 patients had a history of allergies. Although the rate is significantly higher than the general population, the patients experiencing symptoms of shock included three cases of drug-induced shock without a history of allergies. This reaffirms the importance of paying special attention to drug-induced anaphylactoid reactions that may cause sudden symptoms of shock in a patient without a history of allergies. Thirteen patients were treated with epinephrine $(0.5 \pm 0.4 \mathrm{mg})$ and 24 patients with corticosteroids. The outcome was good for all patients, and no biphasic anaphylaxis was observed. Although corticosteroids are not a first-line agent, they may play a role in the prevention of biphasic anaphylaxis.
\end{abstract}

(JJAAM 2006；17：137-41)

Keywords: anaphylaxis, biphasic anaphylaxis, corticosteroids

Accepted for publication on November 21, $2005 \quad$ (05-062)

\section{Introduction}

Anaphylaxis is an acute systemic allergic reaction characterized by rapid onset after exposure to a causative substance ${ }^{1-3)}$. As patients with anaphylaxis transferred emergently mostly have severe symptoms, they are more frequently treated by an emergency physician than allergist, which suggests the importance of the initial treatment. For this reason, treatment of anaphylaxis needs to be provided in compliance with international guidelines ${ }^{4}$. Phy-

\section{Corresponding authors:}

Department of General Medicine and Emergency Care

Toho University Omori Medical Center

6-11-1 Omorinishi, Ota-ku, Tokyo 143-8541, Japan

E-mail; kazunaka@med.toho-u.ac.jp sicians in charge of the initial emergency treatment are and will be required to implement appropriate first-aid measures for patients with anaphylaxis. The biphasic reaction of anaphylaxis is a recurrence of anaphylaxis symptoms after an initial reaction. Because many reports have recommended that patients with anaphylaxis should be observed for 8 to 24 hours to monitor for biphasic reactions, it is important for an emergency physician to understand biphasic reactions. Although there have been occasional reports analyzing patients with anaphylaxis, recently only a few reports about the emergency transfer of adult patients with severe symptoms involving biphasic reaction have been published in Japan ${ }^{5}$. Therefore, the purposes of this retrospective study were to: 1) analyze the clinical data of adult patients with anaphylaxis who were admitted to an emergency unit; 2) report several characteristics observed in these patients; and 3) assess the 
Table1. Etiology of anaphylaxis.

\begin{tabular}{lc}
\hline Cause & No $(\%)$ \\
Food & $12(46)$ \\
Medication & $11(42)$ \\
Bee sting & $1(4)$ \\
Rat bite & $1(4)$ \\
Hamster bite & $1(4)$ \\
\hline Total & $26(100)$ \\
\hline
\end{tabular}

biphasic reaction.

\section{Subjects}

Clinical analysis was conducted for 26 patients with anaphylaxis who were transferred and admitted for emergency treatment at the Toho University Omori Medical Center between September 2003 and August 2005. We studied 12 male patients and 14 female patients aged 17 to 69. Anaphylaxis includes in a broad sense an anaphylactic reaction caused by a type $1 \mathrm{IgE}$-mediated allergy and an anaphylactoid reaction induced by direct stimulation of mast cell degranulation. Because there is not much significance in their clinical differentiation, both are treated as anaphylaxis in this study.

\section{Results}

Possible anaphylaxis triggering factors were foods for 12 patients, drugs for 11 patients, and other factors (bee, rat, and hamster) in three patients (Table 1). The foods included fish for seven patients; meats, soba or buckwheat noodles, and citrus fruits for one patient; and other factors for two patients. The results of a specific RAST were positive for five of the patients. The mean serum IgE level was high with $420 \pm 430 \mathrm{U} / \mathrm{ml}$. All drug-induced cases were caused by oral agents, including NSAIDs for eight patients and antibiotics for three patients. The results of a DLST were positive for two patients. The period between exposure and onset of symptoms ranged from a few minutes to less than an hour, accounting for $24 \pm 28$ minutes and $15 \pm 18$ minutes in the food-induced and drug-induced cases, respectively. There was no significant difference among them. Cutaneous and respiratory symptoms were observed in all patients. Twenty-four patients experienced symptoms of hypoxemia and were treated with oxygen. No tracheal intubation was required. Seven patients experienced symptoms of disturbance of consciousness, and nine patients experienced symptoms of shock, either drug-
Table2. Clinical signs and symptom of anaphylaxis.

\begin{tabular}{lc}
\hline Signs/Symptoms & No $(\%)$ \\
\hline Urticaria, angioedema, flushed skin & $26(100)$ \\
Shortness of breath, dyspnea, wheezing & $26(100)$ \\
Hypotension & $9(35)$ \\
Nausea, vomiting, diarrhea & $8(31)$ \\
Syncope & $7(27)$ \\
Laryngeal edema, tongue swelling & $6(23)$ \\
\hline
\end{tabular}

induced (five patients) or food-induced (four patients) (Table 2). Nine of 12 food-induced cases and 7 of 11 druginduced cases were associated with a history of allergies, that is, 19 of 26 cases in total. Food allergies were the most prevalent among patients with a history of allergies.

Thirteen patients were treated with epinephrine $(0.5 \pm$ $0.4 \mathrm{mg}$ ) and 24 patients with steroids, and three patients with antihistamine. Epinephrine was administered at the mean dose of $0.5 \pm 0.4 \mathrm{mg}$ subcutaneously in nine patients, intramuscularly in one patient, and intravenously in three patients. Hydrocortisone sodium succinates were administered intravenously in eighteen patients at the mean dose of $466 \pm 216 \mathrm{mg}$ (300-1000mg). Methylprednisolone sodium succinates were administered intravenously in three patients at the dose of 300,500 , and $1000 \mathrm{mg}$. Betamethasone was administered intravenously in two patients at the dose of 2 and $8 \mathrm{mg}$. Prednisolone was administered intravenously in a patient at the dose of $60 \mathrm{mg}$. The outcomes were good, and no biphasic reactions were observed in any patients.

\section{Discussion}

This analysis included 26 patients with anaphylaxis who were transferred to a secondary healthcare setting due to dyspnea, which is one of the severe symptoms of anaphylaxis. The primary symptoms of anaphylaxis are cutaneous such as urticaria and angioedema observed in more than $90 \%$ of patients, followed by respiratory symptoms such as dyspnea ${ }^{6,7)}$. It is a coincidence of this study that urticaria and angioedema were observed in all patients.

In this study, detailed questioning was conducted to estimate specific factors because it is extremely difficult to obtain allergen screening such as a loading test as the risks of each test are high. Although the results of a specific RAST were positive for only five patients with foodinduced anaphylaxis, triggering factors were estimated based on a reasonable temporal relationship between the onset of symptoms and exposure to drugs, foods, and other 
factors. The reason why no idiopathic anaphylaxis was observed in this study, even though $37 \%$ of patients were thought to have idiopathic anaphylaxis in a recent report, is uncertain ${ }^{7)}$. However, the detailed questioning could be very important to estimate causative factors in this study. In a recent Japanese report, the probable cause of anaphylaxis was identified in 29 subjects (100\%) of 29 patients, and foods were thought to cause anaphylaxis in 16 subjects (55\%), and medications appeared to cause anaphylaxis in 13 subjects $(45 \%)^{8}$. These observations were similar to the results in this study.

A history of allergies was observed in 19 of 26 patients including 8 of 12 food-induced cases and 7 of 11 druginduced cases. There was no significant difference. However, it should be noted that three patients without a history of allergies presented severe symptoms, such as loss of consciousness and shock. High risk anaphylaxis is generally related to food/drug allergies, bronchial asthma, and atopic diathesis, as well as administration of betablockers $^{9,10)}$. None of the triggers were observed in these three patients. As some cases of drug-induced anaphylactoid reaction may not involve sensitization at onset, it is possible that the first exposure triggers the onset of the clinical syndrome. There are no preventive measures for avoiding unexpected anaphylactic shock in routine medical practice. Here, we are reaffirmed that the risk of anaphylaxis should be kept in mind whenever drugs are administered to patients with or without a history of allergies.

A recent report has suggested that the length of time before the onset of symptoms is reduced and the number of severe clinical symptoms are increased in patients with drug-induced anaphylaxis compared with food-induced cases in Japan ${ }^{8)}$. Although the results of our study indicated a tendency for a reduced length of time before the onset of symptoms in drug-induced anaphylaxis, no significant difference was observed. In addition, four patients experienced food-induced shock that developed rapidly. It is suggested that food-induced anaphylaxis also occurs rapidly in severe cases.

The initial treatment should include maintenance of respiratory and circulatory functions and prevention of the progress of allergic reactions. As is well known, epinephrine is a first-line agent for anaphylaxis ${ }^{11}$. In this study, 13 of 26 patients were treated with epinephrine and did not present with persistent anaphylaxis, which is occasionally observed. Epinephrine was administered at a dose of $0.1 \mathrm{mg}$ to a maximum dose of $1 \mathrm{mg}$ subcutaneously in nine patients, intramuscularly in one patient, and intrave- nously in three patients. No patients experienced adverse effects, such as arrhythmia and elevated blood pressure. According to international guidelines for treatment of anaphylaxis, subcutaneous infusion of epinephrine is not effective in severe cases and intramuscular injection should be provided every five minutes ${ }^{4)}$. The 13 patients treated with epinephrine in this study included patients with severe anaphylaxis presenting shock or disturbance of consciousness who were treated at a higher dose of 0.5 to 1 $\mathrm{mg}$. Intravenous administration was provided for three patients, which is considered rather frequent. Physicians should continue to seek optimal treatment for each pathological condition based on sufficient knowledge of treatment guidelines.

In this study, inpatient treatment is provided for all patients for follow-up observation. Although biphasic anaphylaxis generally occurs in $10 \%$ to $20 \%$ of patients in 8 to 12 hours after resolution of the initial symptoms, no biphasic anaphylaxis was observed in this study ${ }^{12,13)}$. This is primarily attributable to the effects of inflammatory cells by leukocyte chemotactic factors. The clinical characteristics of biphasic anaphylaxis development have not been elucidated. Some reports have indicated that it was prevalent in patients who were orally administered a beta-blocker or an antigen or those with dyspnea or symptoms of shock. Another characteristic has also been suggested in a previous report in which increased incidence was observed in patients treated with insufficient epinephrine at initial treatment ${ }^{14)}$. Another report indicated that biphasic reactions were less likely to present with dyspnea ${ }^{15)}$.

Administration of corticosteroids as the initial treatment is not evidently linked to prevention of biphasic anaphylaxis ${ }^{13)}$. On the other hand, another study suggested that corticosteroids might be beneficial in preventing severity of biphasic anaphylaxis ${ }^{16)}$. Since administration of steroids is not effective for maintenance of respiratory and circulatory functions in the initial treatment, and it may trigger anaphylaxis, careful consideration is required for administration of corticosteroids ${ }^{17)}$. It remains unclear whether corticosteroids given for the initial treatment can prevent biphasic anaphylaxis. However, the absence of or a dose of corticosteroids that is too small given for the initial event may affect the incidence of biphasic anaphylaxis ${ }^{14}$. Considering that the incidence of biphasic anaphylaxis was not observed in any patient in this study, it is highly likely that the initial treatment with corticosteroids prevented the incidence of biphasic anaphylaxis. In this study, hydrocortisone sodium succinate was administrated intravenously in most patients at a dose of 
about $500 \mathrm{mg}$ just after diagnosis of anaphylaxis. It is suggested that early and appropriate doses of corticosteroids may play a role in prevention of biphasic anaphylaxis. However, it is difficult to estimate the effects of different kinds of corticosteroids because our study suffers from the limitations of data in a retrospective analysis. A prospective study, which would be able to estimate the benefit of corticosteroid with biphasic anaphylaxis, will be needed in the future.

\section{References}

1) Kemp SF: Anaphylaxis: current concepts in pathophysiology, diagnosis, and management. Immunol Allergy Clin North Am 2001; 21: 611-34.

2) Kemp SF, Lockey RF: Anaphylaxis: a review of causes and mechanisms. J Allergy Clin Immunol 2002; 110: 341-8.

3) Kaufman DW: An epidemiologic study of severe anaphylactic and anaphylactoid reactions among hospital patients. Epidemiology 1998; 9; 141-6.

4) Cummins RO, Hazinski MF, Baskett PJF, et al: Guidelines 2000 for cardiopulmonary resuscitation and emergency cardiovascular care: an international consensus on science. Circulation 2000; 102: 241-3.

5) Minemura J, Murayama J, Yamanouchi S, et al: Clinical pharmaceutics study of patient carried emergency medical center. Journal of Japanese Society for Emergency Medicine 2000; 3: 472-6. (Japanese)

6) Ditto AM, Harris KE, Krasnick J, et al: Idiopathic anaphylaxis: a series of 335 cases. Ann Allergy Asthma Immunol 1996;
77; 285-91.

7) Kemp SF, Lockey RF, Wolf BL, et al: Anaphylaxis. A review of 266 cases. Arch Intern Med 1995; 155: 1749-54.

8) Nagashima C, Ikuma S, Setoguchi $K$, et al: Clinical analysis of 29 patients with anaphylaxis. Japanese Journal of Allergology 2005; 54: 338. (Japanese)

9) Toogood JH: Beta-blocker therapy and risk of anaphylaxis. CMAJ 1987; 136: 929-33.

10) Toogood JH: Risk of anaphylaxis in patients receiving betablocker drugs. J Allergy Clin Immunol 1988; 81: 1-5.

11) Chamberlain: Emergency medical treatment of anaphylactic reactions. Project Team of The Resuscitation Council (UK). J Accid Emerg Med 1999; 16; 243-7.

12) Brazil E, MacNamara AF: "Not so immediate" hypersensitivity-- the danger of biophasic anaphylactic reactions. Accid Emerg Med 1998; 15; 252-3.

13) Stark BJ, Sullivan TJ: Biophasic and protracted anaphylaxis. J Allergy Clin Immunol 1986; 78: 76-83.

14) Lieberman P: Biphasic anaphylactic reactions. Ann Allergy Asthma Immunol 2005; 95: 217-26.

15) Smit de V, Cameron PA, Rainer TH: Anaphylaxis presentations to an emergency department in Hong Kong: incidence and predictors of biphasic reactions. J Emerg Med 2005; 28: 381-8.

16) Douglas DM, Sukenick E, Andrade WP, et al: Biphasic systemic anaphylaxis: an inpatient and outpatient study. J Allergy Clin Immunol 1994; 93: 977-85.

17) Erdmann SM, Abuzahra F, Merk HF, et al: Anaphylaxis induced by glucocorticoids. J Am Board Fam Pract 2005; 18: 143-6. 


\section{原著論文}

\section{救急搬送されたアナフィラキシー 26 症例の臨床的検討}

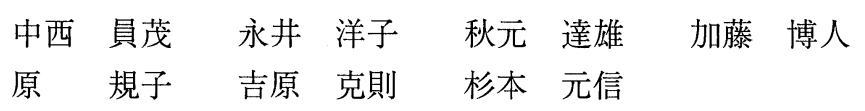

要旨 2003 年 9 月より 2005 年 8 月までの 2 年間に東邦大学医療センター大森病院に 2 次救急搬送され, 入院加 療を行ったアナフィラキシー症例26例に臨床的検討を加えた。アナフィラキシーを引き起こしたと考えられる誘 因物質は, 食物 12 例, 薬物 11 例, その他 3 例（ハチ, ラット, ハムスター) であった。食物では魚介類が 7 例, 肉類 1 例，そば 1 例，かんきつ類 1 例，その他 2 例であった。このうち特異的 radioallergosorbent test（RAST） の陽性例は 5 例であった。薬物は全て内服薬であり, 非ステロイド系消炎鎮痛剂が 8 例, 抗生物質が 3 例であっ た。このうち drug lymphocyte stimulation 試験（DSLT）の陽性例は 2 例であった。症状は皮䖉症状㧍よび呼吸器 症状は全例に認められた。意識障害は 7 例，ショックは 9 例に認められ，そのうち 5 例が薬剂性，4 例が食事性 であり, 特に有意差は認めなかった。アレルギー歴は26例中19例に認められ，一般に比べ有意に高率であるが， ショックを呈した症例のうち 3 例はアレルギー歴を認めない薬剤性であった。薬剤性アナフィラキシー様反応は 過去にアレルギー歴がなく, 突然のショック状態になることがあり, 特に注意が必要であることが再認識される。 治療はエピネフリン投与 $(0.5 \pm 0.4 \mathrm{mg})$ が 13 例, ステロイド投与は 24 例であった。予後は全例良好であり, 遅 発性反応は認められなかった。ステロイドの投与は第一選択薬ではないが遅発相予防としては有益と考えられる。 (日救急医会誌 $2006 ; 17: 137-41$ )

キーワード：アナフィラキシー，遅発性アナフィラキシー，ステロイドホルモン

東邦大学医療センター大森病院総合診療・急病科学講座

著者連絡先：干 145-8541 東京都大田区大森西 6-11-1

原稿受理日：2005年 11 月 21 日（05-062） 